\title{
Digital Survivance: Mediatization and the Sacred in the Tribal Digital Activism of the \#NoDAPL Movement
}

\author{
Lynn Schofield Clark \\ University of Denver \\ Lynn.Clark@du.edu \\ Angel Hinzo \\ University of San Diego \\ AHinzo@sandiego.edu
}

\begin{abstract}
To explore the role of contestation in mediatization processes, this article utilizes digital and visual methods to analyze instances of Indigenous digital survivance. Focusing on recent examples at the heart of the \#NoDAPL movement allows us to flesh out and argue for a decolonizing approach to the study of mediatization, which we define, following Clark (2011), as the process by which collective uses of communication media (1) extend the development of independent media industries and their circulation of narratives, (2) contribute to new forms of action and interaction in the social world, and (3) give shape to how we think of humanity and our place in the world. The article therefore concludes with suggestions regarding the further development of methodological approaches to studying processes of mediatization in relation to contestations over normative claims and pragmatic concerns regarding the role of media systems in our collective future.
\end{abstract}

\section{Keywords}

Indigenous - digital - mediatization - contestation - social change - tribal activism - postcolonial 


\section{Introduction}

The beauty of the earth and its waters figure prominently in the oral traditions, poetry, and fiction of the people indigenous to what is today known as North America. But the status of these lands has been contested since the sixteenth century, when a form of political, epistemic, economic, and subjective management emerged that Anibal Quijano (2000) has termed the "colonial matrix of power (p. 533)." This was a system borne from a struggle over the conquest of the Americas by European monarchies. It legitimized a social classification of race, gender, and religion that in turn gave license to the confiscation of land and the destruction of cultures, and that set the terms for the relations of domination between the conquerors and the conquered. The logics of this colonial matrix of power thus justified hierarchical forms of knowledge, ranking the knowledge of the conquered as inferior and generating what Walter Mignolo (2007) refers to as racial and patriarchal colonial wounds. Recent controversies over land and water rights in the U.S. and Canada, including those related to the Dakota Access and Keystone XL Pipelines, demonstrate the continuation of a longstanding pattern of generating colonial wounds, dispossessing Indigenous persons of the lands and water that are a source of life and are considered sacred. But the logics of coloniality and the continuing processes of generating colonial wounds do not advance without contestation.

This article explores the ways that tensions have unfolded and played out across various media platforms in relation to the Dakota Access Pipeline (DAPL), considering how spaces within social media have become sites for resistance as Indigenous persons use social media to gain visibility, mobilize support, and claim sovereignty, understood as the right to claim authority and autonomy in their (or our) own lands. We consider the questions: how have Indigenous communities utilized social media in efforts to contest normative claims, specifically through land-based concepts of the sacred, and what differences have social media platforms made in these processes of contestation? This is a study of mediatization, in that it explores the interrelations between changes in mediated communication and social life, focusing on the role of media platforms, messages, and everyday communication practices in our collective construction of reality (Hepp, Hjarvard and Lundby, 2015).

We are particularly interested in understanding online artifacts shared via social media as expressions of Indigenous epistemologies, recognizing that Indigenous epistemology can be understood, following Byrd and Rothberg (2011), as "an intellectual project that challenges and disrupts the logics of colonialism that underwrite liberal democracies in order to question Euro-American constructions of self, nation-state, and subjectivity (p. 3)." We refer to participation 
in the circulation of such material through social media practices as forms of digital survivance, following the work of Anishinaabe cultural theorist Gerald Vizenor (1994), who coined the term "survivance" by combining the words survival and resistance. As he wrote: "Survivance is an active sense of presence, the continuance of native stories, not a mere reaction, or a survivable name. Native survivance stories are renunciations of dominance, tragedy and victimry." (p. vii) Digital survivance is thus described here as the digital and visual practices of Indigenous peoples and their allies as they have drawn upon and advanced Indigenous epistemologies and storytelling traditions within the contexts and constraints of social media.

Using digital and visual methods, we analyze artifacts of engagement that speak of the land's sacrality and of Indigenous peoples' survival that have emerged in memes, tweets, artwork, music, poetry, and photos that have appeared on various social media platforms including Twitter, Instagram, Facebook, Pinterest, YouTube, and Tumblr. Aligning our work with Native scholars and decolonizing allies Tekkobe and McKnight (2016), Raynauld and colleagues (2018), Manuelito (2015), McMahon (2014) and others who highlight Indigenous presence in the digital realm, we follow Angela Haas's (2015) suggestion that rather than studying how Indigenous persons are written into digital and visual spaces, we explore the work of Indigenous persons in those spaces.

In this article, we identify four themes in the digital survivance of the \#NoDAPL movement: the recognition of water and land as sacred and necessary for life; contestations against the need to harvest oil from the land; the reliance on Indigenous epistemologies to support the sacred charge to protect land and water for future generations; and the integration of the sacred and the feminine. Focusing on these recent examples of digital survivance allows us to flesh out and argue for a decolonizing approach to the study of mediatization. We utilize an approach in which mediatization is understood and studied, following Clark (2011), as the processes by which collective uses of communication media (1) extend the development of independent media industries and their circulation of narratives, (2) contribute to new forms of action and interaction in the social world, and (3) give shape to how we think of humanity and our place in the world.

We found that the Indigenous artifacts we studied worked to de-link and redefine what is sacralized or revered and taken as beyond question in the U.S. context. In this case, what has been desacralized in the \#NoDAPL movement are the links between the nation, corporate interests, and the politico-religious identities that support them. What has been resacralized are links between water and life, the sacred duty of protecting land and water, and the sacrality of all persons - especially women who have been historically disregarded and 
dismissed. Querying whether processes of desacralization of U.S. epistemologies may be accelerating due to the contexts of social and visual media, then, the article suggests that desacralization might be a useful way of thinking about contestations, and specifically how contestations rooted in liberation might crack open possibilities for reframing ways of understanding the world. In this way, desacralization may play an important role in both considering and fostering social change.

Our focus on Indigenous epistemologies therefore calls into question the ways that theories of mediatization have conceptualized processes of social change, and the role of media institutions in relation to those processes. Mediatization, according to Hjarvard (2013), is the "double-sided development in which media emerge as semi-autonomous institutions in society at the same time as they become integrated into the very fabric of human interaction in various social institutions like politics, business, or family" (p. 30). Many scholars interested in mediatization have thus focused on how societal institutions have changed in relation to one another, often exploring the ways that "media logics" shape other institutions of society such as governance, religion or education (Hepp, 2013; Hjarvard, 2013; Lundby, 2009). Yet we argue that this institutional focus has created a blind spot that has caused those exploring processes of mediatization to overlook the symmetry between the societal institutions of media, governance, education, and religion in colonizing societies. In other words, we have failed to interrogate how these institutions share logics within the structures of differing societies, and thus we have not explored the role media institutions, governance, and religion, as well as academic scholarship, play in upholding shared logics. A decolonial approach that calls into question such linkages therefore also challenges scholars of mediatization to move beyond the realm of abstract analysis, as Indigenous approaches suggest that theories of change require action (Cabral, 1970; DeLoria, 1969).

Some scholars who have looked at changes occurring at the intersection of media and religion, such as Lundby and his colleagues (2018), have foregrounded questions of conflict and contestation, considering how communication media have mediated conflict and, in turn, how such mediatized conflicts have given shape to the institutions of religion writ large over time by shaping the ways that religion is represented, practiced, taught, and negotiated in public spaces. This article seeks to contribute to this body of work by focusing on the role of contestation in mediatization processes, foregrounding conflicts over legitimation by recognizing not the separation between the institutions of media and religion, but the coherence across these institutions, and the conflicts that emerge as that coherence is contested. Consistent with Lövheim and Lied's (2018) discussion of religious controversy as a struggle over claims of normativity, then, this case that explores digital survivance constitutes an 
example of how religion and the sacred are implicated in contestations over the laws of the nation-state and the societal norms that are presumed to uphold them (see also Abdel-Fadil \& Liebmann 2018; Meyer 2018).

After a brief discussion of the controversial building of the Dakota Access Pipeline that sparked the \#NoDAPL movement, and a discussion of the visual and digital methods employed to analyze the artifacts of digital survivance related to the \#NoDAPL movement, this article offers a close examination of these artifacts in relation to the four themes noted above. The article then considers the project of decolonizing theories of mediatization, or theories of media and social change. We begin with a discussion of the \#NoDAPL movement.

\section{\#NoDAPL}

The Dakota Access pipeline, which transports crude oil from northern North Dakota through South Dakota and Iowa to an oil tank farm in Patoka, Illinois, was a $\$ 3.78$ billion project begun in 2014 that received widespread public attention beginning in spring 2016. Opposition to the Dakota Access pipeline began in 2014 when Dakota Access, LLC, a subsidiary of Energy Transfer Partners, LP, announced their intent to construct the underground oil pipeline, challenging the legal rights and sovereignty of the Standing Rock Sioux tribe. When the pipeline received approval from the U.S. government to cross through Sioux and Lakota tribal lands and sacred sites in violation of U.S. treaties, the Standing Rock Sioux and other groups allied to thwart construction through legal action and then through large-scale in-person protests at the site, with young Indigenous people known as the Standing Rock Youth leading the development of the social media campaign to garner support and bring attention to the cause (Hinzo 2018). The Dakota Access Pipeline protests then came to be referred to as \#NoDAPL with reference to the Twitter hashtag and social media campaign that began in spring of 2016. News coverage of the protests did not peak until that fall and winter, as national media outlets finally covered the story of protesters suffering harrassment from federal officers in freezing conditions.

At 1886 kilometers, the Dakota Access pipeline is much shorter in length than the 3456 kilometer (plus $125^{2}$ kilometers in extensions) Keystone XL pipeline that crosses from Alberta, Canada to refineries in Illinois and Texas. Indigenous people had been involved in protesting the Keystone XL pipeline, and the same Trump memorandum that advanced the Dakota Access pipeline in January 2017 also allowed the Keystone XL pipeline to advance. Thus, the \#NoDAPL movement had its beginnings before the Dakota Access pipeline 
itself, and the hashtag has come to refer to a much wider movement extending into the past and the future.

In fact, as early as 2007, tribal leaders were voicing anxieties about the plans to transport oil across the United States through the Keystone XL and other proposed pipelines across territory traditionally occupied by the Lakotas, Dakotas, Arapaho, and other tribal Nations while also crossing 271 bodies of water, including the Mississippi and Missouri rivers (Woodard, 2008). In the late summer of 2011, the Black Hills Sioux Treaty Council, nine member reservations, and dozens of other Native and non-Native groups signed the Mother Earth Accord expressing concerns about the Keystone XL pipeline's possible impact on the Ogallala Aquifer, which is the most important source of water in the High Plains region and is considered sacred water (Woods, 2015). The next year, 20 spiritual chiefs signed a statement declaring their opposition to all pipeline projects, which "threaten the physical, mental, emotional, and spiritual well-being of all of our relations" (Ball, 2012). Then Indigenous organizing started in earnest, as did support for the movement among Native communities.

Signs of this support emerged in a variety of social media platforms. In February 2013, the then-23-year-old Sicangu Lakota rapper Frank Waln, who grew up on the Rosebud reservation and sings with his group Nake Nula Wa'un, released the song Oil 4 Blood which denounced the Keystone XL Pipeline. Waln, who had been previously named Best Producer at the 2010 Native American Music Awards and currently has more than 31,00o followers on Twitter and 7,728 subscribers to his YouTube channel, was featured in MTV's Rebel Music series with Oil 4 Blood, the song that he had been singing on college campuses and for Indigenous groups (ICMN, 2015). Later in 2013, Native American activist and commentator Winona LaDuke (who in 2019 had more than 22,000 Twitter followers) penned an opinion piece that would be widely circulated and later quoted in several \#NoDAPL memes, as we discuss below. LaDuke wrote: "Someone needs to explain to me why wanting clean drinking water makes you an activist, and why proposing to destroy water with chemical warfare doesn't make a corporation a terrorist" (LaDuke, 2013).

In the summer of 2015, according to a report in The New York Times, a small group of young adults who had grown up on the Cheyenne River Reservation in South Dakota had returned to the area and had formed the One Mind Youth Movement in response to several suicides among their peers (Elbein, 2017). That fall, the group worked on the local campaign against the Keystone XL Pipeline, which had been slated to cut under the Cheyenne River upstream from the reservation. Once the Keystone XL permit had been denied in November of 2015 , meaning that no more action was necessary at that time, and after 
Standing Rock Sioux officials and members of the Meskwaki tribe had voiced objections to the Dakota Access Pipeline at public informational meetings at the county and state levels (Dalrymple, 2016), the group moved their attention to the Standing Rock reservation upstream from several Sioux reservations. In April of 2016, the youth group started a prayer camp at the northern end of the Standing Rock Sioux Reservation that they named Sacred Stone, and began life "in ceremony," as they termed it, modeling this prayer camp on one at the Cheyenne River Reservation. By the spring of 2016, Indigenous youth at the Sacred Stone prayer camp at the Standing Rock Sioux Reservation had begun planning runs and marches that extended into the summer, further raising the profile of the protests through social media announcements about these events. By late August, the camp's population at Standing Rock had blossomed into the thousands.

These efforts finally drew international media attention in September, October, and November of 2016, largely in response to the frigid temperatures and militarized police responses that protestors were enduring (Gray, 2016; Silva, 2016). Images of young people, as noted earlier, featured prominently both in the mainstream media attention and in the digital survivance artifacts and narratives that challenged existing relations of power. In September 2016, the elders of the Sioux tribes, who had reestablished a Council Lodge at the Standing Rock prayer camp, gifted the youth at Sacred Stone with a chanupa, a Plains sacred ceremonial pipe symbolizing the harmony of nature and humanity, and the youth were deputized as akicita, a Lakotan term meaning "warriors for the people" (Elbein, 2017).

On December 4, 2016, USACE announced that it was looking at possible alternate routes to mitigate negative environmental effects, granting a major victory to the Standing Rock protesters. But President Trump signed a presidential memorandum to advance the approval of the pipeline on January 24 , 2017. Following that, USACE sent a notice that would allow the pipeline company to drill under Lake Oahe, and the Cheyenne River Sioux then sued, arguing that construction interfered with the religious practices of the tribe and citing an 1851 treaty (Winsor \& Hill, 2017). The protest site at Standing Rock was then closed by government order on February 22nd, with additional arrests made of those refusing to leave. The pipeline was completed in April 2017 and became commercially operational on June $1,2017$.

The hashtags \#NoDAPL, \#StandWithStandingRock, and \#WaterisLife have remained in circulation, in reference to Indigenous efforts to track and publicize oil spills and water contamination resulting from problems with this and with similar pipelines built throughout North America. These hashtags played a key role in the gathering of materials that were analyzed for this article. 


\section{Digital and Visual Methods}

Digital and visual materials that circulate in social media include photos, video, animated gifs, vines, images of words, and memes that combine both image and text and which, according to Shifman (2014), are "creative expressions through which cultural and political identities are communicated and negotiated" (p. 15). Memes are noteworthy for their spreadability, as they are easily captured and shared among internet users. Memes are usually humorous, although some visual materials that include images and words go viral based on their ability to articulate commonly shared beliefs and ideas.

Studying the practices related to the sharing of digital and visual materials online requires a different method of analysis than text characters, as Hjorth and Burgess (2014) have noted. Several researchers have pointed out issues with representativeness that relate to the roles that application programming interfaces (APIS) and algorithms play in shaping what is accessible. As Hogan (2013) explains, "APIs do not give complete access to a data store for a host of reasons such as privacy, intellectual property, ....and mitigating competitiveness," resulting in social media platforms providing data that are not raw and unbiased but rather are manipulated by algorithms (see also Blank, 2017 and Lacy et al, 2015). Additionally, several social media sites and applications such as WhatsApp, Facebook Messenger, and SnapChat are closed, thus making it difficult to access materials from those sites in the building of a complete dataset. Researchers of social media therefore face many challenges in building evidence to support their interpretations.

Hashtags are one important way in which such activity on Instagram has been tracked and analyzed. Location-based queries are another, as Highfield and Leaver (2016) have noted. In this project we have utilized hashtags to clarify intent and context of the sharing of visual materials, and have also sought to follow and interview individual users and communities of interest (Abidin, 2014).

Analysis of digital and visual materials also requires attention to the platforms through which such materials are shared. Instagram, for instance, transitioned its feeds from a chronological to an algorithmic organization scheme in 2016, and then refined the algorithm further in 2018 so that users are now likely to see $90 \%$ of the posts made by friends and family, according to the site (Loren, 2018). Facebook and Twitter had made similar ongoing adjustments between 2016 and 2018, as these platforms attempted to determine what would be most relevant or interesting to each user in order to enhance user engagement on the platform. Although Tumblr was arguably the key sharing site for memes and gifs before 2013 (when Yahoo purchased the site), memes and 
other images began to appear more frequently on Facebook and Twitter after that time (Bereznak, Giorgis, Herman, Knibbs, Luckerson, McHugh, \& Baker, 2017).

Because platform policies and practices are constantly evolving, it can be difficult for users to keep up and remain aware of the nuances of these changes for privacy. In an era of social media, as Matzner and Ochs (2018) have pointed out, the concept of privacy must be understood as inherently social, relational, and sociotechnical and not merely evaluated in relation to individuals. Ascertaining the extent to which online visual material was intended for a broad public or a more private audience can be challenging, therefore. Thus, even as an image might be available for examination and analysis, any such material must be treated responsibly through an "ethics of care" by the research team, which seeks to do no harm in the communities in which we work (Luka, Millette, \& Wallace, 2018). Given the fact that the FBI have infiltrated Indigenous activist activities (Parrish, 2017), it is worth considering how best to conduct research that benefits the Indigenous community while preserving its members' safety.

To explore the ways that social media provide a platform for digital survivance, therefore, we utilized a variety of tools to identify and build a sample of visual materials, referencing feeds of Indigenous social media influencers and relevant hashtags. We collected and coded memes, artwork, photos, and other forms of visual storytelling. Rather than limiting our sample to images circulated on one platform, however, we followed visual materials across various platforms in recognition of the fact that as people traverse differing sites in their everyday lives, they import the techniques, genres, and popular forms of expression from one platform to another (Driscoll and Thorson, 2015; Miltner, 2014).

We began by using Google search as well as searches within individual social media platforms to identify and locate images that had been shared on Instagram, Tumblr, Twitter, Facebook, and individual and organization blogs, utilizing the hashtags \#NoDAPL, \#StandingRock, \#Mni Wiconi, \#freeRedFawn, as well as the keywords "protect the waters", "Dakota Access", and "Dakota Access Pipeline Art", among others. We also used the "more like this" Pinterest feature to allow that platform's algorithm to identify similar phenomena, and searched for memes and images via the Facebook pages of the Ya-Native Network, and, through personal and algorithmic recommendations, searched for memes and original illustrations via the Twitter accounts of @NoDAPL, @StandingRockSioux, @SacredStoneCamp, @LastRealIndians, @najournalists (Native American Journalists), @mkbowannie, @IndianCountryToday, @YaNative,@NativeVoices,@Tomahawk903,@NativePublicMedia,@NCA11944 
(National Congress of American Indians), @180oggnative, @lilnativeboy, @Reamus_Wilson, and @nativeamericanfamilies. Between January and August 2018, after eliminating advertisements and other content that was not linked to NoDAPL either by hashtag or time frame, we curated 463 visual artifacts of digital survivance in a Pinterest file so that others in the Indigenous community could view and comment (see https://www.pinterest.com/lclark2088/ decolonizing-internet-studies/). We attempted to trace collected images to original artists, many of whom had first shared their work with their followers via Instagram. We contacted artists to seek permission to include their work in this article, but were often unable to identify the original source of the image, photo, or meme, although we did notice that several images that had travelled across platforms had originally appeared online in the blogs, Instagram, or Facebook pages of individuals or organizations, or in alternative news sources, dating from the earliest uses of the \#NoDAPL hashtag in the spring of 2016.

We then categorized the images so as to identify themes that emerged in the sample, identifying the centrality of topics such as "water is life" that emerged in a variety of visual and verbal forms. Coding first occurred during the collection phase, as coauthor Hinzo's familiarity with indigenous myths and imagery provided a framework for identifying and later analyzing images in the sample, thus providing a richness to image selection and coding that would not have been possible without her knowledge.

Because of the small size of the sample relative to how many images were shared, we were less interested in counting how often themes appeared or how frequently they were shared than in exploring why these themes might have had resonance among those who shared them. We are also aware that any such analysis of images shared under a variety of differing circumstances risks overlooking the specific contexts that shape original uploads and shares. Whereas links between images and hashtags were often relatively clear, there were occasional instances in which it was impossible to surmise the sharer's intention. Future research in this area could experiment with Google's Cloud Vision API that allows researchers to build custom models so as to classify images into multiple categories. We note, therefore, that studying social media phenomena involves not only exploring the practices of users, networks, content, and interactions, but understanding the social contexts in which such materials are shared and the affordances and changes of platforms, including their relation to other social media platforms, and we recognize the limitations of this study. Of particular interest to us, however, were the many instances in which the visual materials included intertextual references that would be recognizable, legible, or humorous primarily to members of Indigenous communities and their allies. 


\section{Visual and Social Media in the \#NoDAPL Movement}

In this section, we elaborate on the four themes we observed in the instances of digital survivance that challenge normative U.S. approaches to the rights of people and of corporations to the use of natural resources. First, we found that among the most frequent and recurring instances of digital survivance related to the \#NoDAPL movement were the images, memes, and other online artifacts that articulated the defense of water as a sacred duty of Indigenous persons. Second, we found contestations to taken-for-granted understandings of the need to harvest oil, thus contesting corporate interests and the U.S. governmental actions that lent support to those interests. These instances were related to a third theme: that of Indigenous prophecies and traditions. We found that instances of digital survivance in the \#NoDAPL movement drew upon specific Indigenous prophecies related to the black snake, referenced such traditions as the chanupa, and referenced the Indigenous principle of the seventh generation, as we discuss further below. Finally, we found a prominence of the feminine as it surfaced in relation to the sacred, both with reference to the sacred duties of protection and in relation to the sacrality of land and water. Each of these themes highlight the ways that contestations against the pipeline projects came to be understood as part of a sacred effort that sought to draw into question the normative colonialist claims of human sovereignty over the land and its resources.

\section{$1 \quad$ Water Is Life: the Sacred Duty of Protecting Land and Water}

Water, which had been a central theme in the Keystone XL protests, was the most common source of imagery in the memes and protests of \#NoDAPL, with many images and memes featuring the Lakotas phrase, Mni Wiconi, which means water is life.

Images and videos featuring the words Mni Wic(h)oni and Water is Life were shared on Twitter, Instagram, Facebook, Pinterest, YouTube, and on numerous blogs and websites between spring 2016 and as late as early 2018, and were tagged with \#WaterIsLife, \#NoDAPL, \#MniWic(h)oni, \#StandWithStandingRock, \#stoppipelines, \#ReZpectOurWater, and \#TarSands, among others. Sometimes, these images featured drawings or photos that referenced Indigenous persons, as represented in the feminine image below with braided hair, red skin, traditional dress, and beads. Other visuals similarly incorporate the symbolism of the circle and the colors of red, yellow, black and white, the colors central in what European settlers term the medicine wheel. While this concept of the medicine wheel has differing referents depending on the language of each Native nation, and is protected among some Nations and therefore 


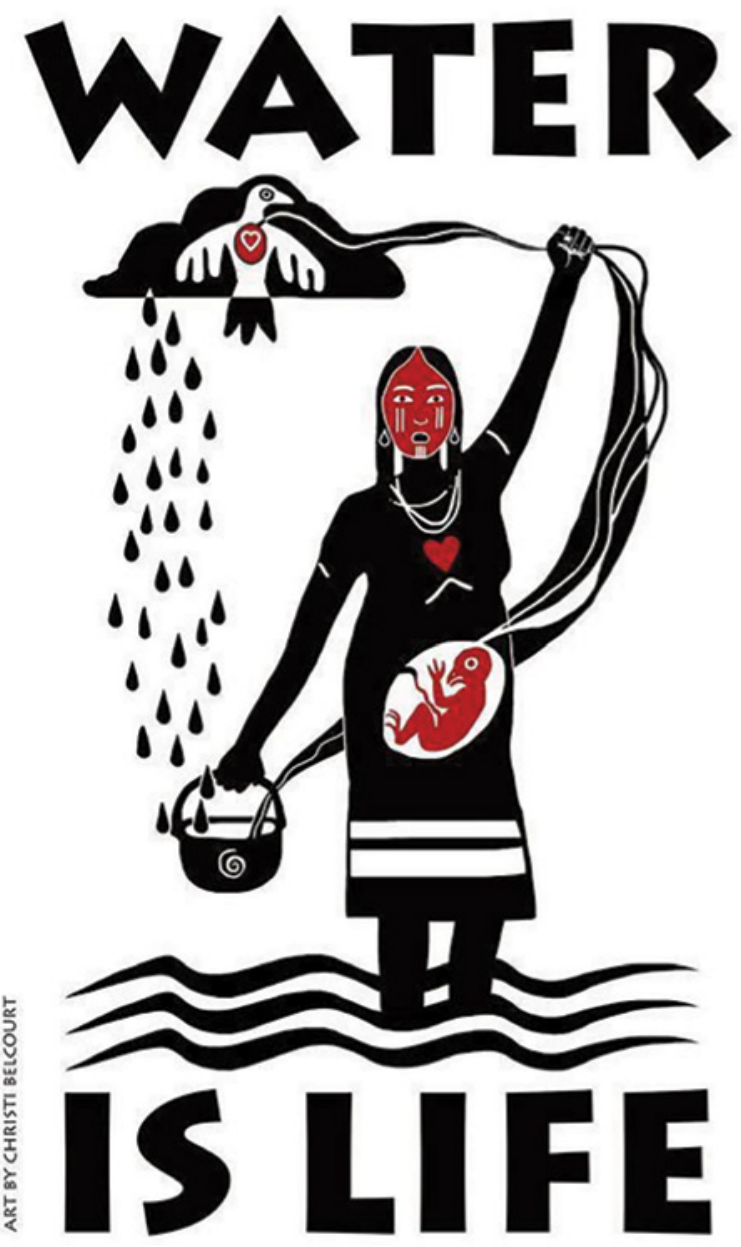

FIGURE 1 Image by Michif (Metis) artist Christi Belcourt. Used with permission.

cannot be further discussed here, it is broadly associated with the circle of life. Other images featured contemporary depictions of contestations, such as the image of members of Indigenous nations and their allies protesting the Kinder Morgan Trans Mountain pipeline that crosses Alberta and British Columbia and transports oil to China via rail from Portland, Oregon (U.S.). References to the phrase "water is life" were also found in relation to the hashtag \#worldwatercrisis. Both this and the \#NoDAPL hashtag were linked via accounts on Twitter, Instagram, and Facebook, and appear side-by-side on various activist websites with similar contestations over water in Chile, Kenya, Haiti, Ghana, Thailand, India, and Flint, Michigan (U.S.). This speaks to the ways in which 
themes of the \#NoDAPL movement began to reach beyond the particular issue of the pipelines crossing the U.S. and to wider contestations over resources and human/water management. In this sense, then, the \#NoDAPL protests can be understood as part of a larger series of contestations that destabilize assumptions of colonialist claims of human sovereignty over the land and of the global power vested in multinational corporations that increasingly exerts influence over several national and transnational institutions of government. As rights to land and water are central to the \#NoDAPL protests, they evoke and desacralize what is known as the discovery doctrine. This is a concept rooted in a $15^{\text {th }}$ century papal decree that legitimized colonization by directing European Christian rulers to "capture, vanquish, and subdue the saracens, pagans, and other enemies of Christ" and to "take all their possessions and property" (Davenport 1917). In the early $19^{\text {th }}$ century Supreme Court case Johnson $v$. McIntosh (1823), the discovery doctrine was employed to justify the dispossession of U.S. Indigenous lands. The case granted that the U.S. had exercised the right of "discovery" in taking possession of lands from the natives, who were deemed "heathens." The Christian doctrine of discovery thus became the cornerstone of U.S. Indigenous policy. The contemporary contestations against U.S. governmental and corporate claims to sovereignty therefore can be viewed as participants in broader challenges to existing relations of power that implicate the U.S.'s Christian heritage and that bring Indigenous commitments to the sacred to bear in these contestations.

2

\section{Contesting Taken-for-Granted Understandings of the Need to Harvest Oil}

As noted earlier, in 2013 Indigenous activist Winona LaDuke had written: "Someone needs to explain to me why wanting clean drinking water makes you an activist, and why proposing to destroy water with chemical warfare doesn't make a corporation a terrorist" (LaDuke, 2013).

In the summer and fall of 2016, LaDuke's words were referenced as on the poster below and in other images that were posted and shared on Tumblr, СвС News, and on various Indigenous and activist blogs, tagged with \#NoDAPL, \#nodakotaaccesspipeline, \#nativeamerican, \#savetheplanet, \#firstnation, \#Indigenous, \#sevengenerations, and \#resistance, among other tags. Similarly, the title of Sicangu Lakota rapper Frank Waln's 2013 song reemerged as the hashtag \#Oil4Blood and was referenced as late as fall of 2017 on Instagram in reference to a Keystone pipeline leak in South Dakota. These examples contest the taken-for-granted approach to drilling for oil as an acceptable and normal practice in the U.S. that have played out in relation to U.S. government 


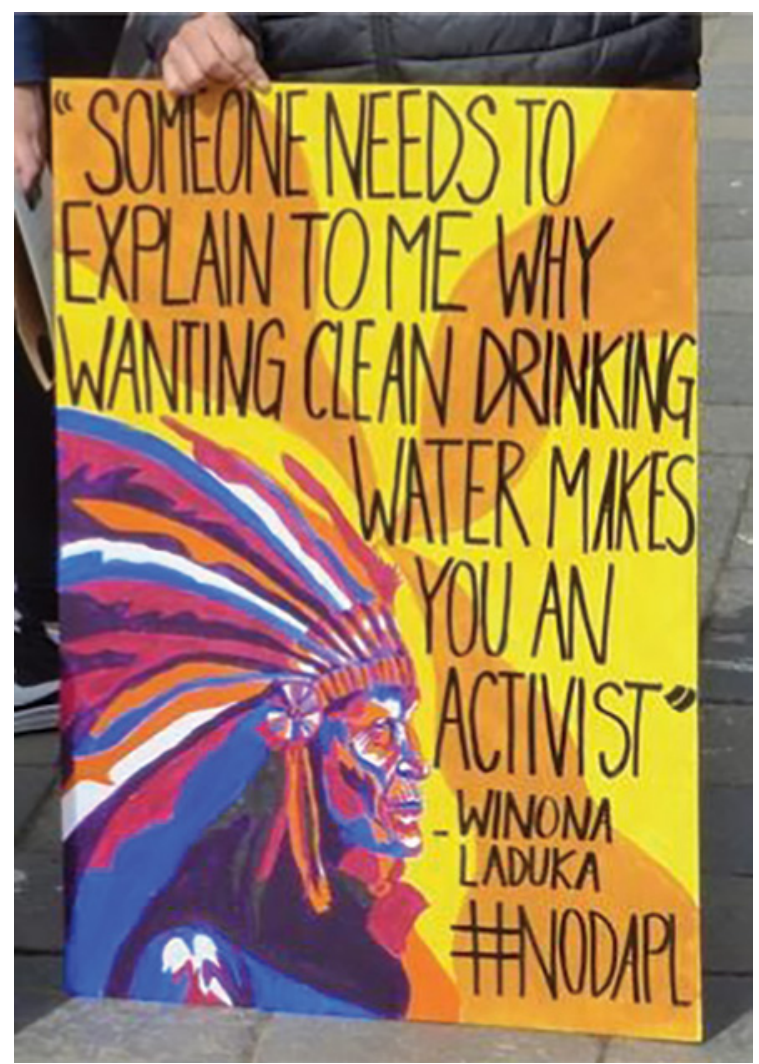

FIGURE 2 Image labeled for noncommercial reuse on Google Image search.

support of industrial growth that foregrounds business priorities over mounting evidence of the destructive impact of these priorities on all life. The contestations thus suggest that extractive practices have high human costs while highlighting the connections between humanity and the need for clean drinking water. Identifying the conflict between corporate gain and human need has been a central theme in the digital survivance of the \#NoDAPL movement, as we discuss further below.

Sacrality and the Protection of Land and Water: the Black Snake, the Seventh Generation Principle, and the Chanupa Pipe

Land stewardship principles are central to Native American epistemologies and spiritual practices. Many origin stories of Indigenous people of the Americas include emerging from the earth or being placed in specific areas, creating 
ties to the land itself. Additionally, many geographical features, including waterways and mountains, are considered sacred, sentient, and enspirited with First Peoples, beings that prepared the world for humans.

Addressing the conflict between human and corporate interests has therefore been linked with sacrality, as championing human need over corporate greed became infused with a sense of purpose and responsibility among young Indigenous people in the year leading up to the most visible \#NoDAPL protests in 2016, as noted earlier. The black snake of Lakota cosmology came to be identified with pipelines, and thus imagery of the black snake figures into the artwork, music videos, and memes circulating in relation to the \#NoDAPL movement in 2016 and later. This aspect of Lakotan cosmology holds that a black snake will bring destruction to the Lakota people and Earth. Additionally, many Indigenous communities in the Americas hold what has been termed the Seventh Generation Principle. According to this principle, Indigenous communities must look seven generations ahead when considering the environmental impacts of human actions. Thus this principle is related to sustainability, and calls upon Indigenous persons to defend against the destruction symbolized in the black snake.

The image below features a black snake that is being halted by an eagle, with other circulating images featuring the snake crushed in the hand of an Indigenous person person. In one image, an Indigenous person is inside and operating through the body of an eagle and is subduing the snake that also

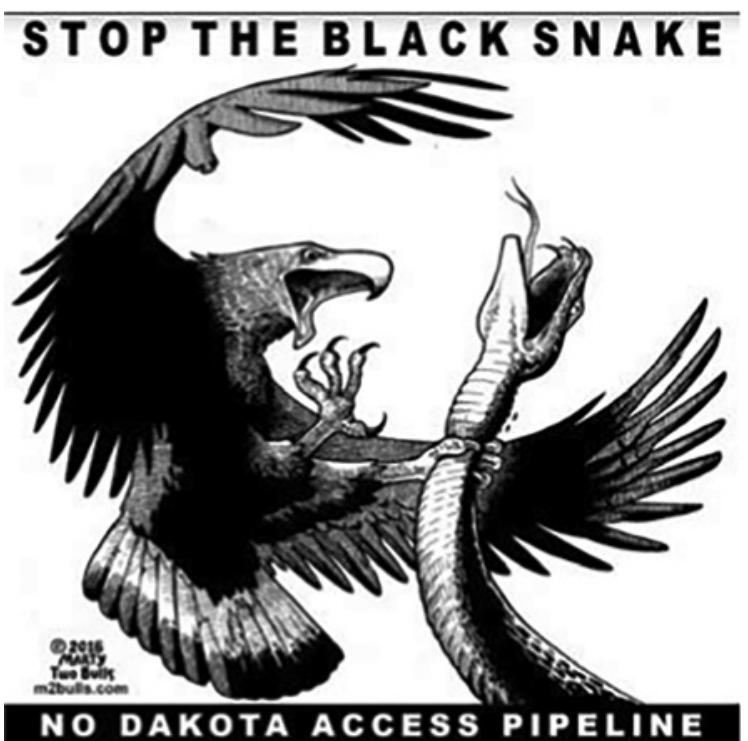

FIGURE 3 Image by Oglala Lakota artist Marty 2Bulls. Used with permission. 


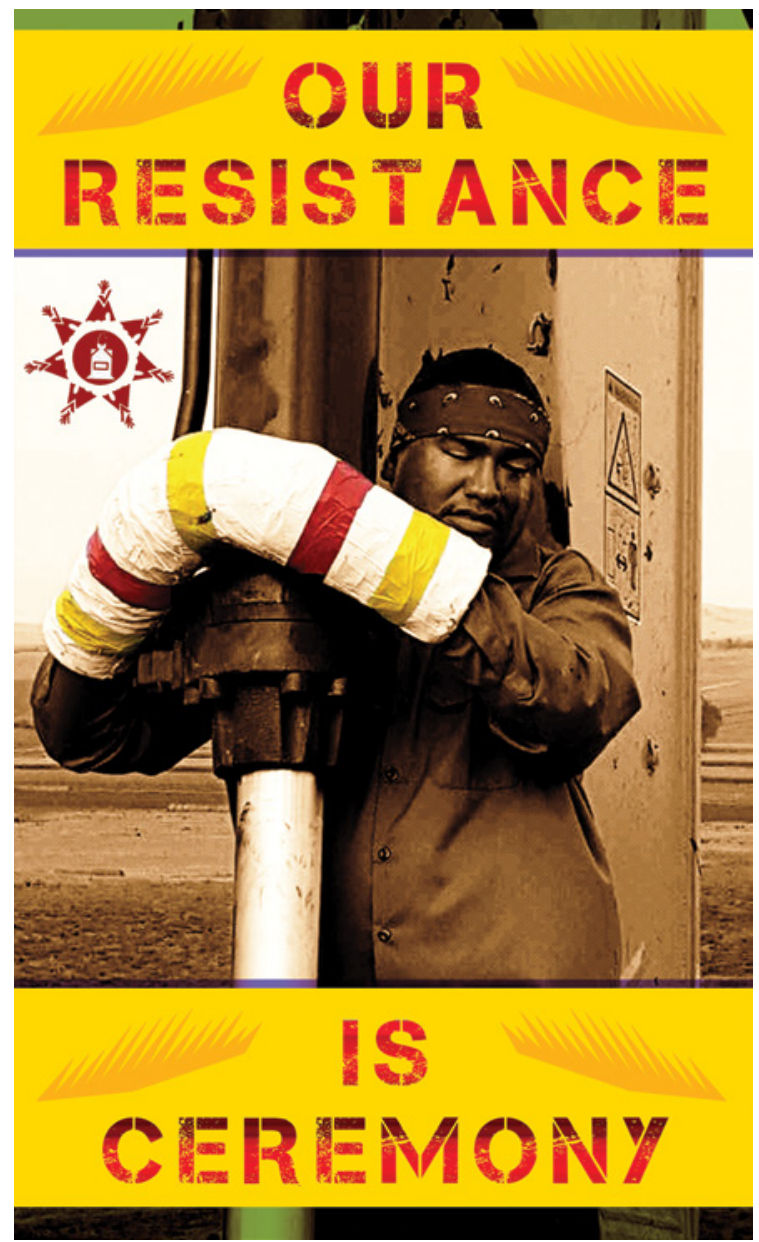

\#NODAPL \#NOCOLONIZERS \#DESTROYTHEPIPELINE

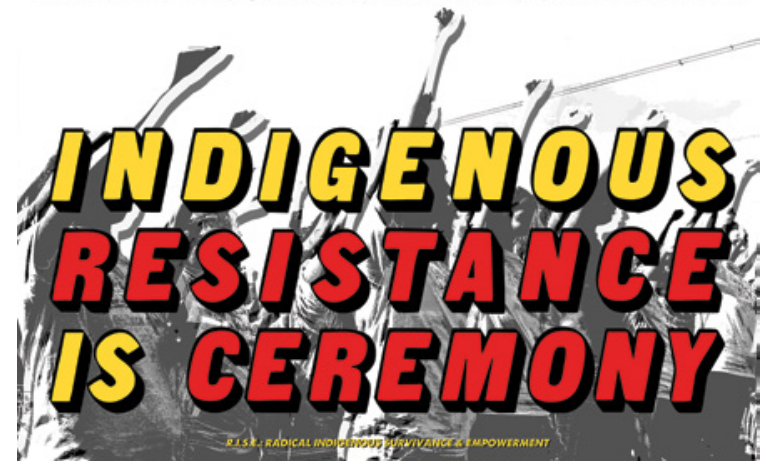

FIGURE 4 Images by Demian DinéYazhi' in Apogee Journal. Used with permission. 
has a human face. In another, where a sectioned snake is featured on a yellow background, the image bears a likeness to the snake featured on the Gadsen flag designed during the American revolution that was adopted by the libertarian U.S. Tea Party movement beginning in 2009. The Gadsen flag includes the motto, "Don't tread on me." The sectioned snake was also depicted in Benjamin Franklin's "Join, or Die" cartoon meant to symbolize the importance of a unified nation of colonies in opposition to English monarchical regulations. Thus, the use of this image is explicitly political, linking an approach to freedom from government regulations with the freedom to pollute and destroy the harmony of water and earth, and calling for resistance to governmental policies that support the building of the pipelines.

These images, many of which were created by Indigenous artists, were shared on Instagram, Twitter, Facebook, and Pinterest in the summer and fall of 2016, and tagged in reference to \#NoDAPL, \#KilltheBlackSnake, \#protectoursacred, \#StandingRock, and @LastRealIndians, among others.

The above image highlights the Indigenous view of resistance not as disruption or as a form of civil unrest, but as a form of ceremony. Other images illustrate the ways in which several themes converge and overlap within the visual media shared on social media platforms to reveal the centrality of the sacred in these contestations, with references to the chanupa pipe, a powerful tool of prayer and communication with the Creator and spirits, as a contestation to the pipelines transporting oil, and images of contemporary resistance linked with the black snake and the Seventh Generation principle and with protectors bearing traditional Indigenous markings.

\section{4}

\section{The Sacred and the Feminine}

The centrality of Native American women and girls in the instances of visual and digital survivance that we have reviewed here and that emerged in our larger collection of materials reflect the interconnections between the Earth and femininity within Indigenous American epistemologies. Additionally, these images relate to social media activism regarding missing and murdered Indigenous women (\#MMIW) and the overwhelming rates of violence inflicted on Indigenous women in North America. In many traditional Indigenous epistemologies, women are viewed as the caretakers of the land and are associated with the health of the Earth. Balance of the world includes the balance of feminine and masculine spirits associated with earth and sky respectively. Acts of violence inflicted on land through resource extraction parallels violence inflicted on Indigenous American women and creates an environment that fosters sex trafficking and violence. Indigenous American women have the highest rates of sexual assault and are more than 2.5 times as likely to be targeted for sexual violence as non-Indigenous women (Gilpin, 2016). Various 


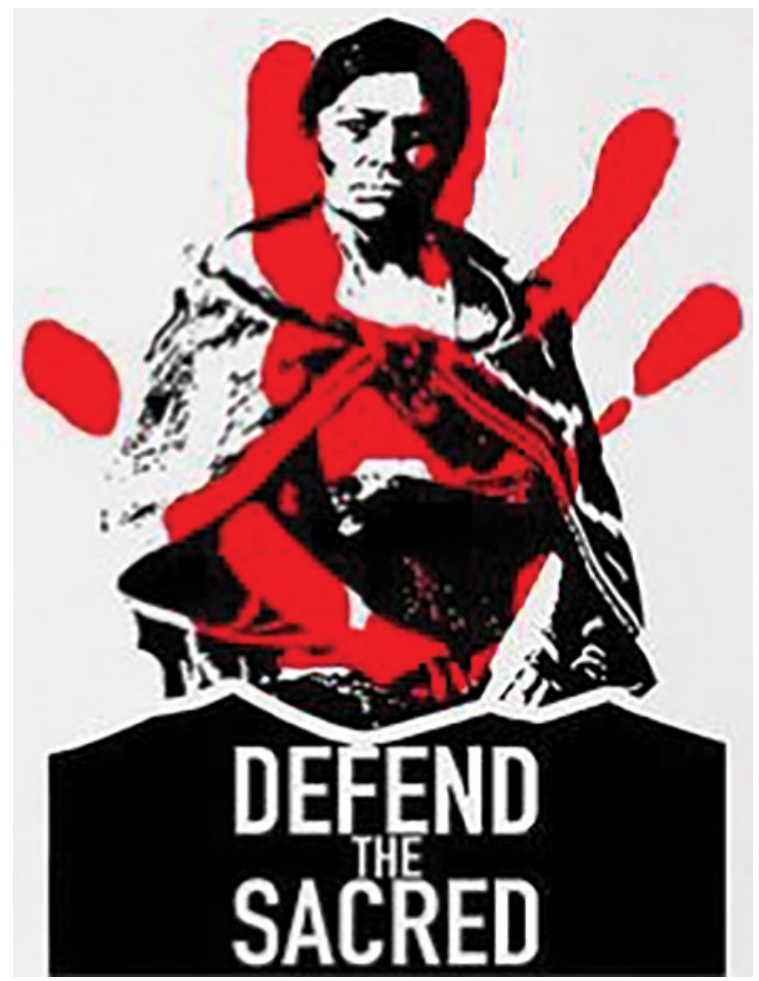

FIGURE 5 Image by unnamed artist.

SOURCE: INDIGENOUS ACTION.

Native American Studies scholars have attributed these rates of violence to the legacy of colonization. As Muscogee (Creek) scholar Sarah Deer (2009) notes, "Rape and sexual violence are deeply embedded in the colonial mindset...Sexual assault mimics the worst traits of colonization on its attack on the body, invasion of physical boundaries, and disregard for humanity (p. 150)." In 2017 Amnesty International included violence against Indigenous women as one of three primary concerns regarding the impacts of energy development on tribes. Their report noted that an oil boom in North Dakota resulted in a $300 \%$ increase in assault and sex crimes which reflects the general trend relating energy development projects with increased rates of sex trafficking. Amnesty International (2017) reported, "Energy development projects threaten to exacerbate an already acute crisis for Native American and Alaskan Native women who lack meaningful protection, respect, or fulfillment of their basic human rights to live free from violence (p. 2)." Images associated with \#NoDAPL and the Standing Rock protests highlight the role of Indigenous 
women in protecting the land and the need to defend the exploitation of both land and Indigenous women.

In the image above, an Indigenous woman is featured as a protector and defender of the sacred. Two similar images that were circulated highlighted the ways Indigenous women have been victimized: one meme noted that one in three Indigenous women are victims of sexual assault, and another highlighted injustices perpetrated against women who were participating in acts seeking to protect the land and water. These images and memes shared common tropes of braided or long black hair and Indigenous clothing as noted in the earlier section, but as illustrated here and as evidenced throughout our sample, instances of digital survivance depict Indigenous women of differing shapes, ages, and even differing levels of passivity and outrage. Taken together, these images contest narratives that would contain Indigenous women into a monolithic representation.

In spite of the fact that the pipeline became commercially operational in 2017, the \#NoDAPL oppositional movement has continued in relation to other pipeline projects. Both environmentalist and Indigenous groups continue to follow and highlight stories of pipeline leaks and spills. The \#NoDAPL movement has so far shown signs of enormous staying power (Bubacz, 2018; InFocus, 2018) and, as we have discussed, is best understood on a much longer timeframe that begins before the \#NoDAPL protests and will extend its influence far into the future. We argue that its staying power is due in part to the way religion and the sacred are implicated in Indigenous contestations over normativity such as those found in the \#NoDAPL movement, and this staying power also raises interesting questions as a case study for mediatization, as we will discuss further in the section that follows.

In this section, we have explored what we have termed the digital survivance of the \#NoDAPL and related movements, understood here as the digital and visual practices of Indigenous peoples and their allies as they have drawn upon and advanced Indigenous epistemologies and storytelling traditions within the contexts and constraints of social media. We have focused on artifacts of engagement related to these movements that, as they have been shared with others via social media, have contested both U.S. corporate/legal approaches to land and water rights and have therefore enabled those viewing these images to draw connections between Indigenous epistemologies and contestations to U.S. government policies. Further, through allusions to the sacred duty to defend and protect the land and water, we have highlighted how these artifacts have contested the approach to human sovereignty over land that Indigenous communities associate with colonialism and with the dominant U.S. religious tradition of Christianity, desacralizing U.S. 
Christian approaches while resacralizing Indigenous approaches. We have also highlighted the prominence of the feminine in these artifacts, noting the significance of gendered representations as a trope in the Indigenous imagination that serves as a further means of contesting the male/female and human/ nature dichotomies of domination associated with the U.S.'s Christian and colonialist heritage.

\section{Discussion: Desacralization and Contestation}

If sacralization is the process by which certain ideas and values come to be not only beyond examination but also deemed exemplary and linked with the moral expression of a culture, then desacralization is a process that involves calling into question those ideas and their presumed link to values and morality. Like decolonization, desacralization involves recognizing that knowledge is not a neutral category but rather is a consolidation of epistemic authority, which affords certain groups the power to lay claim to the truth. Processes and practices of desacralization challenge the moral foundation of that epistemic authority, and thus also challenge claims of what is good, right, and worthy of reverence. Both decolonization and desacralization call into question narrow and ethnocentric approaches that constrain our ability to think, know, and act. Processes of desacralization therefore create an opening for reflection and action, and must be better understood in relation to social change.

In his discussion of the center and periphery of society, Shils (1970) argued that elites have the authority to lay claim to an affinity between the sacred and their own values, symbols, beliefs and actions, making themselves in effect the custodians of the sacred. Gordon Lynch (2012) has thus further observed that the decolonialist turn has led to a sustained critique of the essentialized concepts of the 'sacred' that emerged out of a specific western intellectual, cultural, and political history (see also Taves, 2009). This, in turn, has led scholars to theorize the sacred as a boundary-marker for identities and as an expression of collectively held significant moral commitments (Sumiala, Lundby and Salokangas, 2006). Reviving an interest in Durkheimian sociology, Lynch (2012), building on Jeffrey Alexander (2005)'s discussions of the sacred as a type of signifier associated with the profound, truthful, and valuable, has argued that what a culture holds sacred emerges in relation to historically specific collective experiences of agency, structure, and practice. Robert Bellah (1967) argued that such commitments in the context of U.S. culture could be understood as a form of civil religion in which the nation and attendant symbols such as the flag, the pledge of allegiance, and the national anthem come to have profound 
meaning. Bellah has been criticized for his failure to acknowledge that what has sacred form in a context of nationalism can be a force of evil rather than good, an idea that Alexander (2009) elaborates in his study of the ways that the Holocaust has emerged as a moral symbol of the capacity for human evil in the form of German nationalism. In other words, when that which is sacralized is put in service of the nation and hence in the service of those in power, the sacred can be corrupted.

Alexander and his co-authors (2006) have argued that in successful struggles, such as in the U.S. civil rights movement of the 1960s, "out-groups" are able to marshal favorable representations that are then translated into solidarity and identification, which is a necessary precursor for the support of what they term "civil repair," which may come in the form of regulatory interventions. Lynch (2012), building on Couldry and Curran's (2003) notion of the legacy media as reflecting and constructing the 'sacred center' of society, has thus noted that the media participate in the constructing, the reifying and contesting of the sacred, because they collectively allow for the translation of representations into both identification and action. People articulate their collective moral convictions and politico-religious identities through both traditional and social media, which frame, amplify, and provide the platform for the performance of societal conflicts (Clark, 2003, 2007; Hjarvard, Mortensen, and Eskjaer, 2015; Hoover, 2006; Hoover and Coats, 2016). For this reason, as Lynch (2012) has argued, media "can be reasonably claimed to be one of, if not the, primary social institutions engaged in the reproduction, celebration and contestation of sacred forms in late modern society."

Social movements can act as catalysts for change as they frame events in ways that may either expose or hide the rationales by which certain unjust practices have been sacralized (Williams, 2007). Social media play an important role in allowing social movements to coalesce as people personalize the goals of movements and then share them among their networks (Bennett \& Segerberg, 2013; Papacharissi, 2013). Previous work has indeed explored the ways that online responses to the Keystone XL Pipeline were personalized and shared in social media, especially among anti-pipeline activists who utilized Twitter (Hodges and Stocking, 2014). We similarly argue that online responses to the Dakota Access and other pipelines have been amplified through social media. Further, by underscoring the presence of the Indigenous sacred, we argue that the instances of digital survivance reviewed here worked to desacralize the U.S. nation and its unquestioned assertion of the right to claim a moral authority. The combination of imagery of the sacred and the amplification of social media allowed for much wider processes of desacralization than had been possible previously, as such messages in social media persist over 
time and are rendered endlessly findable through search algorithms, so that others who later become interested in what is desacralized can find and can share them again in new contexts (boyd, 2010). Platforms like Instagram and Tumblr are designed to host materials that are continuously available for such remixing and recreating of user-generated content. We believe that this contestation thus holds the possibility of contributing to an ongoing destabilization of Christianity's unquestioned hegemony and moral authority in U.S. society.

We also want to situate our project in relation to the anti-colonialist writings of Amilcar Lopes da Costa Cabral, who emphasized the importance to the formation of a liberation movement of a shared culture and shared lived experiences among oppressed persons. Cabral (1970) reminds us that in order for culture to play a role in shaping the framework of a liberation movement, a movement must be able to preserve the positive values of a well-defined social group. Further, Cabral observes the need for liberated infrastructures that allow for the combatting of colonial propaganda and the building of alternative systems of transport and communication that can unite oppressed people across distance (Cabral, 1970). We believe that our study underscores the way in which the \#NoDAPL movement has done and continues to do this, not only for individuals who might "personalize" the movement but also by reinforcing and expressing positive cultural values of and for Indigenous persons in the service of the struggle. This form of "connective action" (Bennett \& Segerberg, 2013) thus provides the movement with the potential for a national dimension, as Cabral argues, as it allows for both for the preservation and survival of the cultural values of the people and for the harmonization and development of these values within a national framework. Furthermore, our study and theories of decolonization remind us that women are pivotal to how nations are imagined and mapped (Goeman, 2013). The technology makes it possible for the development of this new national dimension, as we collectively gain awareness both of the struggle for survival and of the role of technology as employed in support of or to suppress that struggle.

In an earlier essay, coauthor Clark (2014) argued:

mediatization theorists can play a role in commenting on and participating in envisioning actual changes in our media systems. To do this, theorists will need to consider how to act as bridges between critical actors and the social movements that work beyond research institutions. Individuals and groups in the realms of practice and activism are much more directly involved in the processes of change, and as they must address the ethical and political problems that arise on a regular basis, those in academia could - and should - work to support their efforts. 
In this sense, mediatization theory has a largely underexplored pragmatic dimension, following Peirce's sense of the pragmatic as the productive crafting of sharper habits of thought that are particularly pertinent to our collective existential situation (Peirce, 1958; see also Hickman, 2007).We argue that it is therefore important for those of us interested in mediatization and its decolonization to think about the role of media in relation to both state legitimation and the restriction of state jurisdiction while also considering how Indigenous claims to sovereignty can be granted legitimacy for belonging and reward. As our study suggests, there is a need to press news media to move beyond frames of order and disorder so as to employ frames of criminality on the part of the state when appropriate. There is also a need to support the ever-increasing media savvy of those engaged in desacralizing contestation so as to prick the conscience of those in power via social media.

This study suggests next steps for research as well, such as: is the linkage of the sacred to contestations of colonialism appearing more or less frequently than may have been the case in pre-digital settings? Do references to the sacred and to possible existential crises broaden an anti-colonialist movement's reach and effectiveness? We will only be able to answer these questions at a later time, but it is our hope that this work has helped to identify a starting point for deepened exploration into this area for the future.

\section{Conclusion: Digital Survivance as an Element of Accelerated Desacralization}

We have concluded that contestation, when it is at its heart about liberation, can preserve and celebrate the positive cultural values of an historically oppressed social group (in this case, the Indigenous in North America) while also placing these values in the service of the struggle for a respected, autonomous nationhood. Suggesting that processes of desacralization may be accelerating due to the contexts of social and visual media, the article has therefore pointed out that desacralization and resacralization might be a useful way of thinking about how contestations rooted in liberation might crack open possibilities for reframing ways of understanding the world, and thus may play an important role in fostering social change. As such, a focus on desacralization and resacralization opens the possibility for focusing on how certain patterns of being and knowing persist, even in spite of all efforts - intentional or otherwise - to suppress, shape, control, or change.

Artifacts of digital survivance speak not only of contesting power, then, but of how the communities that create and circulate these artifacts make 
a claim to and speak from a moral center, thus displacing and decentering the claim of the normative, and even of how we define and understand "power" and "the center." Our contributions to discussions of the role of contestation in processes of mediatization, then, lies in an examination of how certain elements of a society are deemed moral, sacred, and worthy of reverence, and how those come to be called into question through what we have discussed as processes of desacralization and resacralization. These processes are not about violence as they are usually framed within legacy media, although they are about disruption. Decolonization, as Maldonado-Torres (2007) has argued, is a gift, and an invitation to engage in dialogue. It demands responsibility and the willingness to acknowledge and consider the ways of knowing, being and doing of both the colonized and the colonizer.

Theories about change matter. In today's context of communication and cultural change, we as researchers might be expected to think not only about what is, but about what we as a society might collectively become. By engaging in an iterative process of tracing artifacts of digital survivance and other artifacts of engagement as they are shared in particular contexts and as they contribute to efficacy within social movements, we argue that researchers in mediatization may be in a strong position to offer important contributions that bridge between research, social movements, and societal institutions.

Mediatization, or the rise of social media and the affordances it offers to those who would seek to communicate widely and creatively, makes the kind of digital activism that this article has reviewed possible. But it is the people and their will to survive that infuse these artifacts of digital survivance with imagination, and hope. It is they who constitute and breathe life into digital survivance. The indigenous epistemological foundation that underscores these artifacts of digital survivance reminds us that even in a time of heightened precarity, and even when Indigenous persons recognize the destructive directions of change, they - or we - can find ways to persist and survive together.

\section{References}

Abidin, C. (2014). \#In\$tagLam: Instagram as a Repository of Taste, a Burgeoning Marketplace, a War of Eyeballs. In M. Berry \& M. Schleser (Eds.), Mobile Media Making in an Age of Smartphones. New York: Palgrave Macmillan US, pp. 119-128.

Alexander, J.C., Giesen, B., and Mast, J. (2006). Social Performance: Symbolic Action, Cultural Pragmatics and Ritual. Cambridge: Cambridge University Press. Alexander, J. (2006). The Civil Sphere. New York: Oxford University Press. 
Alexander, J. (2009). Remembering the Holocaust. New York: Oxford University Press. Amnesty International. (2017, March 2). Testimony and recommendations from Amnesty International USA regarding the impacts of energy development on tribes. AmnestyUSA.org. Retrieved from https://www.amnestyusa.org/files/pdfs/un_spec rap_conslutation.pdf.

Ball, D. (2012, November 12). Spiritual leaders vow to defend Mother Earth from oil sands and pipelines with spiritual declaration. Indian Country Today. Retrieved from https://indiancountrymedianetwork.com/news/environment/spiritual'-leaders -vow-to-defend-mother-earth-from-oil-sands-and-pipelines-with-spiritual-decla ration/.

Bellah, R. (1967). Civil religion in America. Daedalus 96(1), pp. 1-21.

Bennett, W.L. and Segerberg, A., 2013. The Logic of Connective Action: Digital Media and the Personalization of Contentious Politics. Cambridge: Cambridge University Press.

Bereznak, A., Giorgis, H., Herman, A., Knibbs, K., Luckerson, V., McHugh, M., Baker, K. (2017, November 29). Roundtable: What happened to Tumblr? The Ringer. Retrieved from: https://www.theringer.com/tech/2017/11/29/16713354/david-karp-tumblr.

Blank, G. (2017). The Digital Divide among Twitter Users and Its Implications for Social Research. Social Science Computer Review 35(6), pp. 679-697.

boyd, d. (2010). Social Network Sites as Networked Publics: Affordances, Dynamics, and Implications. In: Z. Pappacharissi, Ed., A Networked Self: Identity, Community and Culture on Social Network Sites. New York: Routledge. pp. 39-58.

Bubacz, K. (2018, February 28). What Happened after Standing Rock? For Many People, Tearing Down the Camp was Just the Beginning. Buzzfeed. Retrieved from: https:// www.buzzfeed.com/katebubacz/what-happened-after-standing-rock.

Byrd, J. \& M. Rothberg. (2011). Between Subalternity and Indigeneity. International Journal of Postcolonial Studies 13(1), pp. 1-13.

Cabral, A. (1970, 20 February). National Liberation and Culture. (Transl. from French by Maureen Webster). Eduardo Mondlane Memorial Lecture Series, Syracuse, NY.

Clark, L.S. (2003). From Angels to Aliens: Teenagers, the Media and the Supernatural. New York: Oxford University Press.

Clark, L.S., Ed. (2007). Religion, Media, and the Marketplace. New Brunswick, NJ: Rutgers University Press.

Clark, L.S. (2011). Considering Religion and Mediatisation through a Case Study of J+K's Big Day (The J K Wedding Entrance Dance): A Response to Stig Hjarvard. Culture and Religion 12(2), pp. 167-184.

Clark, L.S. (2014). Mediatization: Concluding Thoughts and Challenges for the Future. In: A. Hepp \& F. Krotz, eds., Mediatized Worlds: Culture and Society in a Media Age. London: Palgrave MacMillan, pp. 307-323.

Couldry, N. \& Curran, J. (2003) Contesting Media Power: Alternative Media in a Networked World. Lanham, MA: Rowman \& Littlefield. 
Dalrymple, A. (2016). Audio: Tribe Objected to Pipeline Nearly 2 Years before Lawsuit. Bismark Tribune. Retrieved from: http://bismarcktribune.com/news/stateand-regional/audio-tribe-objected-to-pipeline-nearly-years-before-lawsuit/ article_51f94b8b-1284-5da9-92ec-7638347feo66.html.

Davenport, F.G. (1917) European Treaties bearing on the History of the United States and its Dependencies to 1648, Vol. 1, Washington, D.C.: Carnegie Institution of Washington.

Deer, S. (2009). Decolonizing Rape Law: A Native Feminist Synthesis of Safety and Sovereignty. Wicazo Sa Review 24(2), pp. 149-167.

DeLoria, V. (1969). Custer Died for Your Sins: An Indian Manifesto. University of Oklahoma Press.

Driscoll, K. \& Thorson, K. (2015). Searching and Clustering Methodologies: Connecting Political Communication Content across Platforms. The ANNALs of American Academy of Political and Social Science 659(1), pp. 134-148.

Elbein, S. (2017, January 31). The Youth Group that Launched a Movement. The New York Times. Retrieved from: https://www.nytimes.com/2017/01/31/magazine/theyouth-group-that-launched-a-movement-at-standing-rock.html.

Gilpin, L. (2016, June 7). Why Native American Women Still Have the Highest Rates of Rape and Assault. High Country News. Retrieved from: https://www.hcn.org/ articles/tribal-affairs-why-native-american-women-still-have-the-highest-rates-of -rape-and-assault.

Gray,J. (2016, September 8). Standing Rock: The Biggest Story that No One's Covering. Indian Country Today Media Network. Retrieved from: https://indiancountrymedianetwork.com/news/opinions/standing-rock-the-biggest-story-that-no-ones-covering/.

Haas, A. (2015). Toward a Decolonial Digital and Visual American Indian Rhetorics Pedagogy. In: L. King, R. Gubele, \& J.R. Anderson, Eds., Survivance, Sovereignty, and Story: Teaching American Indian Rhetorics. Logan: Utah State University Press. pp. 188-208.

Hepp, A. (2013). Cultures of Mediatization. Cambridge: Polity Press.

Hepp, A., Hjarvard, S., \& Lundby, K. (2015). Mediatization: Theorizing the Interplay between Media, Culture and Society. Media, Culture \& Society 37(2), pp. 314-324.

Hickman, L. (2007). Pragmatism as Post-Modernism: Lessons from John Dewey. New York: Fordham University Press.

Highfield, T. and Leaver, T. (2015). Instagrammatics and Digital Methods: Studying Visual Media, from Selfies and GIFs to Memes and Emoji. Communication Research and Practice 2(1), pp. 47-62.

Hinzo, Angel. (2018). "We're Not Going to Sit Idly By": 45 Years of Tribal Activism along the Missouri River in Nebraska. Decolonization: Indigeneity, Education \& Society 7(1), pp. 199-214.

Hjarvard, S. (2012). Doing the Right Thing: Media and Communication Studies in a Mediatized World. Nordicom Review 28(2), pp. 105-134.

Hjarvard, S. (2013). The Mediatization of Culture and Society. London: Routledge. 
Hjarvard, S., Mortensen, M., \& Eskjær, M. (2015). Three Dynamics of Mediatized Conflicts. In: M. Eskjær, S. Hjarvard and M. Mortensen, eds, The Dynamics of Mediatized Conflicts. New York; Peter Lang, pp. 1-27.

Hjorth, L., \& Burgess, J. (2014). Intimate Banalities: The Emotional Currency of Shared Camera Phone Images during the Queensland Flood Disaster. In: G. Goggin, L. Hjorth, eds. The Routledge Companion to Mobile Media. London: Routledge, pp. 499-513.

Hodges, H. \& Stocking, G. (2015). A Pipeline of Tweets: Environmental Movements' Use of Twitter in Response to the Keystone XL pipeline. Environmental Politics 25(2), pp. 223-247.

Hogan, B. (2013). Comment on Elena Pavan/1. Considering Platforms as Actors. Sociologica 2013/3, pp. 1-14.

Hoover, S. (2006). Religion in the Media Age. London: Routledge.

Hoover, S. \& Coats, C. (2016). Does God Make the Man? Media, Religion, and the Crisis of Masculinity. New York: New York University Press.

ICMN (Indian Country Media Network) (2015, September 16). 50 Faces, Part viII:Waln, Thunder, Halbritter, Campbell, Bedard. Indian Country Today. Retrieved from: https://indiancountrymedianetwork.com/news/native-news/50-faces-part-viii -waln-thunder-halbritter-campbell-bedard/.

InFocus. (2018, March 8). Standing Rock: One Year Later. APTN News. Retrieved from: http://aptnnews.ca/2018/03/o8/standing-rock-one-year-later/.

Lacy, S., Watson, B., Riffe, D., \& Lovejoy, Jennette. (2015). Issues and Best Practices in Content Analysis. Journalism \& Mass Communication Quarterly 92(4), pp. 791-811.

LaDuke, W. (2013, July 2). When Drones Guard the Pipeline: Militarizing Fossil Fuels in the East. Indian Country Today. Retrieved from: https://indiancountrymedianetwork.com/news/opinions/when-drones-guard-the-pipeline-militarizing-fossil -fuels-in-the-east/.

Livingstone, S. \& Lunt, P. (2014). Mediatization: An Emerging Paradigm for Media and Communication Studies. In: K. Lundby, ed. Mediatization of Communication. Berlin: De Gruyter Mouton, pp. 703-724.

Loren, T. (2018, June 4). The New Instagram Site: Here's How It Works. Later. Retrieved from: https://later.com/blog/instagram-algorithm-update/.

Lövheim, M. and Lied, L. (2018). Contesting Religion. In K. Lundby, ed., Contesting Religion: The Media Dynamics of Cultural Conflicts in Scandinavia. Berlin: DeGruyter, pp. $65^{-80 .}$

Luka, M.E., Millette, M., and Wallace, J. (2017). A Feminist Perspective on Ethical Digital Methods. In Kinder-Kurlanda, K. \& Zimmer, M., eds., Internet Research Ethics for the Social Age: New Challenges, Cases, and Contexts. New York: Peter Lang.

Lundby, K. (2009). Mediatization: Concept, Changes, Consequences. New York: Peter Lang. 
Lundby, K., Ed. (2018). Contesting Religion: The Media Dynamics of Cultural Conflicts in Scandinavia. London: DeGruyter.

Lynch, G. (2012). The Sacred in the Modern World. Oxford, UK: Oxford University Press. Manuelito, B.K. (2015). Creating Space for an Indigenous Approach to Digital Storytelling: 'Living Breath' of Survivance within an Ashinaabe Community in Northern Michigan. Dissertation, Antioch University Ph.D. Program in Leadership and Change. Retrieved from: https://aura.antioch.edu/etds/212/.

Matzner, T., and Ochs, C. (2017). Sorting Things Out Ethically: Privacy as a Research Issue Beyond the Individual. In: Kinder-Kurlanda, K. \& Zimmer, M., eds., Internet Research Ethics for the Social Age: New Challenges, Cases, and Contexts. New York: Peter Lang, pp. 39-52.

McMahon, R., O'Donnell, S., Smith, R., Walmark, B., Beaton, B., \& Simmonds, J. (2011). Digital Divides and the 'First Mile': Framing First Nations Broadband Development in Canada. The International Indigenous Policy Journal 2(2). Retrieved from: http://ir .lib.uwo.ca/iipj/vol2/iss2/2 DOI: 10.18584/iipj.2011.2.2.2.

Meyer, B. (2018). Afterword: Media Dynamics of Religious Diversity (p. 333-338). In K. Lundby, ed., Contesting Religion: The Media Dynamics of Cultural Conflicts in Scandinavia. Berlin: DeGruyter, pp. 333-338.

Mignolo, W. (2007). Introduction: Coloniality of Power and De-colonial Thinking. Cultural Studies 21(2-3), pp. 155-167.

Miltner, K.M. (2014). "There's No Place for Lulz on LOLcats": The Role of Genre, Gender, and Group Identity in the Interpretation and Enjoyment of an Internet Meme. First Monday, 19(8).

Parrish, W. (2017, December 11). An Activist Stands Accused of Firing a Gun at Standing Rock. It Belonged to her Lover - An FBI Informant. The Intercept. Retrieved from https://theintercept.com/2017/12/11/standing-rock-dakota-access-pipeline-fbi -informant-red-fawn-fallis/.

Papacharissi, Z. (2013). Affective Publics: Sentiment, Technology, and Politics. New York: Oxford University Press.

Peirce, C.S. (1958). The Philosophy of Peirce: Selected Writings. London: Routledge.

Quijano, A. (2000). Coloniality of Power, Eurocentrism, and Latin America. Nepantia: Views from the South 1(3), pp. 533-580.

Raynauld, V., Richez, E., \& Morris, K.B. (2018). Canada is \#IdleNoMore: Exploring Dynamics of Indigenous Political and Civic Protest in the Twitterverse. Information, Communication \& Society 21:4, pp. 626-642.

Shifman, L. (2014). Memes in Digital Culture. Boston: MIT Press.

Shils, E. (1970). Selected Essays by Edward Shils. Chicago: University of Chicago Press. Silva, D. (2016, October 27). Dakota Access Pipeline: More than 100 Arrested as Protesters Ousted from Camp. NBC News. Retrieved from: https://www.nbcnews.com/news/ us-news/dakota-access-pipeline-authorities-start-arresting-protesters-new-camp -n674066. 
Sumiala, J. Lundby, K., \& Salokangas, R. (2006). Implications of the Sacred in (Post) Modern Media. Goteborg: NORDicom.

Taves, A. (2009). Religious Experience Reconsidered: A Building Block Approach to the Study of Religion and Other Special Things. Princeton, NJ: Princeton University Press.

Tekkobe, C., \& McKnight, J.C. (2017). Indigenous Cryptocurrency: Affective Capitalism and Rhetorics of Sovereignty. First Monday 21(10).

Vizenor, G. (1994). Manifest Manners: Narratives on PostIndian Survivance. Lincoln, NE: University of Nebraska Press.

Williams, R. (2007). The Languages of the Public Sphere: Religious Pluralism, Institutional Logic, and Civil Society. Annual Academy of Political and Social Sciences 612, pp. 42-61.

Winsor, M. \& Hill, J. (2017, February 9). Cheyenne River Sioux Tribe Files 1st Legal Challenge over Dakota Access Pipeline Easement. $A B C$ News. Retrieved from http://abcnews.go.com/US/cheyenne-river-sioux-tribe-files-1st-legal-challenge/ story? $\mathrm{id}=45373370$.

Woodard, S. (2008, April). Tribes and Landowners in the Dakotas Face Down Giant Pipeline: State Department Hands Out Tobacco, Stirs Anxiety. Indian Country Today. Retrieved: https://stephaniewoodard.blogspot.com/2011/10/tribes-and-land owners-in-dakotas-face.html?m=1.

Woods, C. (2015). The Great Sioux Nation vs. the Black Snake: Native American Rights and the Keystone XL Pipeline. Buffalo Human Rights Law Review 22, pp. 67-261. 